\title{
Histone acetyltransferase-deficient p300 mutants in diffuse large $B$ cell lymphoma have altered transcriptional regulatory activities and are required for optimal cell growth
}

\author{
Leila Haery', Julián G Lugo-Picó ${ }^{1}$, Ryan A Henry², Andrew J Andrews² and Thomas D Gilmore ${ }^{1 *}$
}

\begin{abstract}
Background: Recent genome-wide studies have shown that approximately $30 \%$ of diffuse large B-cell lymphoma (DLBCL) cases harbor mutations in the histone acetyltransferase (HAT) coactivators p300 or CBP. The majority of these mutations reduce or eliminate the catalytic HAT activity. We previously demonstrated that the human DLBCL cell line RC-K8 expresses a C-terminally truncated, HAT-defective p300 protein (p300 $\Delta$ C-1087), whose expression is essential for cell proliferation.
\end{abstract}

Methods: Using results from large-scale DLBCL studies, we have identified and characterized a second C-terminally truncated, HAT-defective p300 mutant, p300 $\mathrm{CC}-820$, expressed in the SUDHL2 DLBCL cell line. Properties of p300 $\triangle$ C-820 were characterized in the SUDHL2 DLBCL cell line by Western blotting, co-immunoprecipitation, and shRNA gene knockdown, as well by using CDNA expression vectors for p300 $\Delta \mathrm{C}-820$ in pull-down assays, transcriptional reporter assays, and immunofluorescence experiments. A mass spectrometry-based method was used to compare the histone acetylation profile of DLBCL cell lines expressing various levels of wild-type p300.

Results: We show that the SUDHL2 cell line expresses a C-terminally truncated, HAT-defective form of p300 (p300 $\mathrm{C}$-820), but no wild-type p300. The p300 $\Delta$ C-820 protein has a wild-type ability to localize to subnuclear "speckles," but has a reduced ability to enhance transactivation by transcription factor REL. Knockdown of p300AC-820 in SUDHL2 cells reduced their proliferation and soft agar colony-forming ability. In RC-K8 cells, knockdown of p300 $\mathrm{C}$ - 1087 resulted in increased expression of mRNA and protein for REL target genes A20 and IKBa, two genes that have been shown to limit the growth of RC-K8 cells when overexpressed. Among a panel of B-lymphoma cell lines, low-level expression of full-length p300 protein, which is characteristic of the SUDHL2 and RC-K8 cells, was associated with decreased acetylation of histone $\mathrm{H} 3$ at lysines 14 and 18.

Conclusions: The high prevalence of p300 mutations in DLBCL suggests that HAT-deficient p300 activity defines a subtype of DLBCL, which we have investigated using human DLBCL cell lines RC-K8 and SUDHL2. Our results suggest that truncated p300 proteins contribute to DLBCL cell growth by affecting the expression of specific genes, perhaps through a mechanism that involves alterations in global histone acetylation.

Keywords: p300, B-cell lymphoma, Histone acetyltransferase, SUDHL2, REL, H3 acetylation

\footnotetext{
* Correspondence: gilmore@bu.edu

'Department of Biology, Boston University, 5 Cummington Mall, Boston, MA 02215, USA

Full list of author information is available at the end of the article
} 


\section{Introduction}

Diffuse large B-cell lymphoma (DLBCL) accounts for approximately $30 \%$ of B-cell lymphoma cases [1]. Molecular profiling of DLBCL cell lines and patient tumors has led to the identification of distinct subtypes, which has been a useful tool in predicting patient survival and therapeutic response [2]. Genome-wide studies have shown that approximately $30 \%$ of DLBCL tumors harbor mutations in two highly related histone acetyltransferase (HAT) genes, EP300 and CREBBP [3-7].

EP300 and CREBBP encode related HATs, p300 and CBP, respectively, that have widespread genomic effects on chromatin structure and gene expression as well as non-genomic effects on protein function [8]. These HATs serve as coactivators for many transcription factors, either through acetylation of lysine residues on histones to modify DNA structure at sites of active transcription or through acetylation of transcription factors to modify their activity. In both cases, the centrally-located, catalytic HAT domain is required for these effects on transcription. Consistent with its broad role in transcriptional control, p300 can directly interact with a wide variety of transcription factors, including NF-kB $[9,10]$, p53 [11,12], MyoD [13], HIF-1 $\alpha$ [14], BRCA1 [15], and Ets-1 [16]. In addition, p300 and CBP contain several protein-protein interaction domains and can exhibit HAT-independent functions; for example, p300 can enhance transcription simply by recruiting proteins to transcriptional start sites, including members of the transcription pre-initiation complex and the RNA polymerase holo-enzyme $[8,17]$.

Most p300/CBP mutations identified in DLBCL are point mutations, nonsense mutations, or deletions that disable HAT activity $[3,5,10,18]$. In some epithelial cancers where a truncated $\mathrm{p} 300 / \mathrm{CBP}$ protein is expressed, the wild-type allele is silenced or otherwise inactivated [19], and ectopic expression of wild-type p300 in some HATdeficient p300 cancer cell lines slows cell growth $[7,20]$. Such results have led p300 to be classified as a tumor suppressor, arising from the hypothesis that it is the loss of wild-type p300 activity which contributes to oncogenesis.

We have previously shown that, due to a 3 ' alteration in one copy of the EP300 gene, the DLBCL cell line RC-K8 expresses a C-terminally truncated HAT-deficient p300 protein (herein called p300 $\triangle \mathrm{C}$-1087). Even though the other copy of the EP300 locus appears intact, RC-K8 cells express low to undetectable levels of wild-type p300 mRNA and protein $[10,18]$. We previously reported that the RC-K8 p300 $\Delta \mathrm{C}-1087$ could not act as a coactivator for the REL transcription factor [18]. Of note, knockdown of $\mathrm{p} 300 \Delta \mathrm{C}-1087$ expression reduces the proliferation and soft agar colony-forming ability of RC-K8 cells [18], and re-expression of wild-type p300 is tolerated in RC-K8 cells, but sensitizes them to the cell killing effects of small-molecule BCL6 inhibitors [7]. Other studies have demonstrated that expression of a HAT domain mutant of p300 results in increased proliferation of hematopoietic stem and progenitor cells, whereas complete loss of p300 does not [21]. Such findings suggest that p300 HAT activity normally limits B-cell proliferation, and that expression of $\mathrm{p} 300$ proteins with an inactive catalytic domain contributes to B-cell growth, survival, and tumorigenesis.

In this report, we have characterized a truncated p300 protein expressed in the DLBCL cell line SUDHL2. We show that this C-terminally truncated and HATdeficient p300 mutant is a weak transcriptional coactivator, and that its expression is required for the optimal growth of SUDHL2 cells. These results and others suggest that expression of $\mathrm{C}$-terminally truncated p300 coactivators defines a subset of DLBCL that utilize distinct oncogenic pathways.

\section{Results}

\section{The SUDHL2 DLBCL cell line expresses a C-terminally} truncated $\mathrm{p} 300$ protein

Pasqualucci et al. [3] reported that several human DLBCL cell lines, including BJAB, Farage, SUDHL2 and SUDHL8, express no detectable full-length $\mathrm{p} 300$ protein. Because of our ongoing interest in p300 mutations in DLBCL $[10,18]$, we sought to further characterize p300 status in these four cell lines. In particular, the reported absence of full-length p300 in BJAB and Farage cells is in contrast to our previous findings [10] and those of others [7,22-25]. Therefore, we reassessed p300 expression in these four DLBCL cell lines by Western blotting of whole-cell extracts, and included multiple independent cell lines in our analyses (including the ones used by Pasqualucci et al. [3]). As a further control, we analyzed RC-K8 cells, which we have previously shown express little or no full-length p300 $[10,18]$. As shown in Figure 1a, multiple isolates of BJAB, Farage, and SUDHL8 cells express easily detectable levels of full-length p300. In contrast, RC-K8 and SUDHL2 cells do not express detectable levels of full-length p300.

Although full-length p300 is not expressed in RC-K8 cells, these cells do express a C-terminally truncated p300 protein (p300 $\Delta$ C-1087) [10,18]. Due to the absence of full-length p300 in SUDHL2 cells (Figure 1a) and the reported nonsense mutation at EP300 codon 821 in these cells [3], we next determined whether SUDHL2 cells express a C-terminally truncated form of p300. Western blotting using an antibody against $\mathrm{N}$-terminal sequences of p300 showed that SUDHL2 cells express a smaller form of p300 under conditions where there is no detectable full-length p300 (Figure 1b). Consistent with the size expected for the reported codon 821 nonsense mutation [3], the single anti-p300-reactive protein in SUDHL2 cell lysates migrated at approximately $90 \mathrm{kDa}$ (herein called p300 $\Delta$ C-820). 

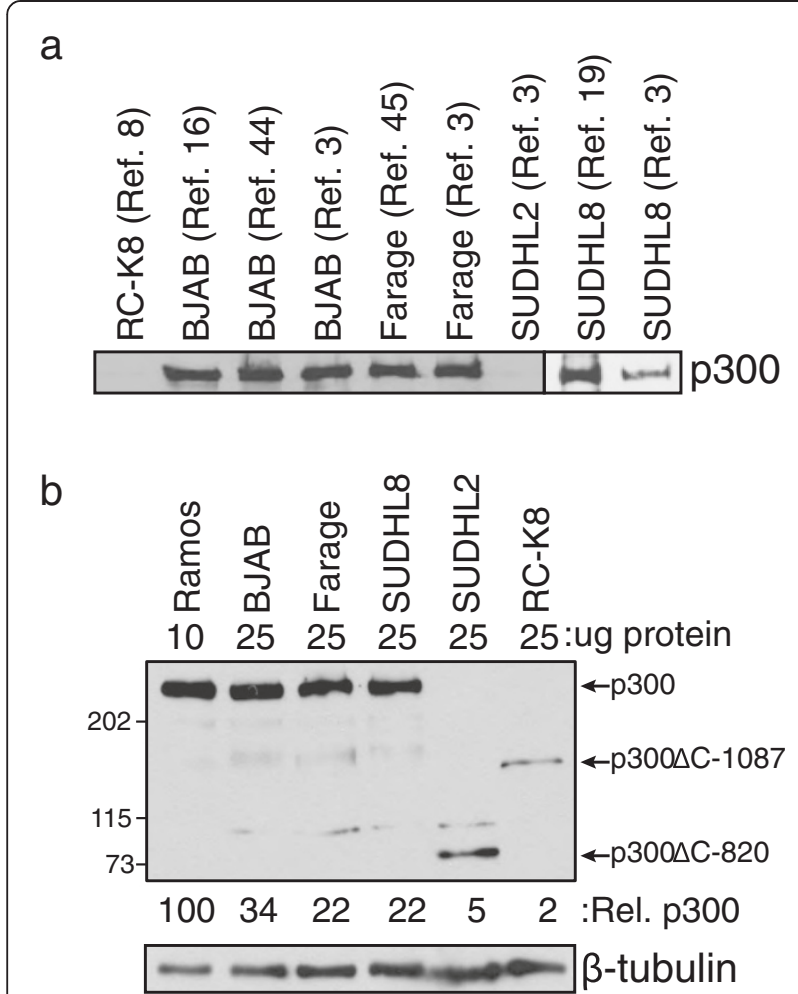

C

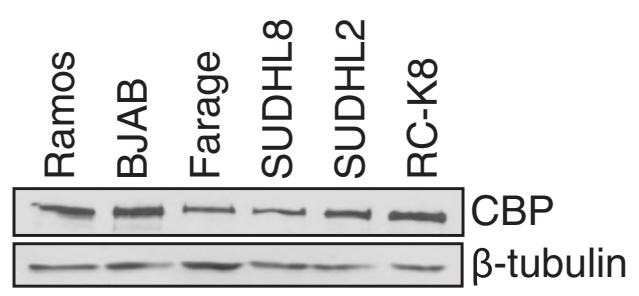

Figure 1 Expression of $\mathrm{p} 300$ proteins in DLBCL cell lines.

(a) Anti-p300 Western blotting was performed on whole-cell extracts from the indicated $D L B C L$ cell lines. The sources of the cell lines are described in Materials and methods and in the indicated references in the figure. Thirty-five $\mu \mathrm{g}$ of total protein from whole-cell extracts was loaded for all samples except for RC-K8 $(50 \mu \mathrm{g})$. (b) SUDHL2 cells express a C-terminally truncated p300 protein (p300 $\Delta$ C-820). Whole-cell extracts from the six indicated cell lines were analyzed by Western blotting for relative expression of p300. The amount of total cell protein loaded is indicated. Western blots were performed with N-terminal anti-p300 antiserum. p300 expression was quantified by densitometric analysis and is relative to full-length p300 in Ramos cells (100). Relative p300 expression for the SUDHL2 and RC-K8 cell lines was determined by analyzing the bands corresponding to p300 $\Delta C-820$ and p300 $\Delta C-1087$, respectively. Full-length p300 in SUDHL2 and RC-K8 cell lines was undetectable (0). (c) Whole-cell extracts from the six indicated $\mathrm{DLBCL}$ cell lines were analyzed by Western blotting for expression of CBP. Twenty-five $\mu \mathrm{g}$ of whole-cell extract was used for each sample. Western blotting was performed with anti-CBP and anti- $\beta$-tubulin (as a loading control) antisera.

Pasqualucci et al. [3] reported that SUDHL2 cells are hemizygous for the EP300 gene and contain only the codon 821 mutant allele. To confirm that SUDHL2 cells lack wild-type EP300 sequences, we PCR-amplified and then sequenced EP300 genomic DNA flanking codon 821 in exon 14. Our results confirmed that the amplified DNA only contained the C2856T mutation (CAG to TAG) at codon 821 in exon 14 (Additional file 1), demonstrating that there is no wild-type EP300 locus in SUDHL2 cells.

Quantitation of p300 levels indicated that the truncated p300 proteins in RC-K8 and SUDHL2 cells are expressed at low levels compared to full-length p300 in four other B-lymphoma cell lines (Figure 1b, relative p300 values). In contrast, the levels of the related HAT CBP were similar in all six cell lines, and certainly did not vary depending on whether a given cell line expressed fulllength or truncated p300 (Figure 1c). These results demonstrate that neither overexpression of mutant p300 nor compensatory changes in CBP expression occurs in B-lymphoma cell lines expressing truncated p300 mutants. Instead, the expression of a truncated p300 appears to be associated with reduced expression of full-length p300.

\section{Characterization of the $\mathrm{p} 300 \Delta \mathrm{C}-820$ protein from SUDHL2 cells}

To further characterize the $\mathrm{p} 300 \Delta \mathrm{C}-820$ protein, we created a CMV promoter-based plasmid expression vector for p300 $\Delta$ C-820 by mutating codon 821 to a stop codon in a full-length p300 cDNA, based on the nonsense mutation in SUDHL2 genomic DNA. When transfected into A293T cells, the synthetic p300 $\Delta$ C-820 cDNA directed the expression of a protein that nearly co-migrated with p300 $\Delta$ C-820 from SUDHL2 cells (Figure 2a).

We next analyzed the subcellular localization of ectopically expressed p300 $\Delta$ C-820 in transfected fibroblasts. As shown in Figure 2b, overexpressed wild-type p300, p300 $\Delta \mathrm{C}-1087$, and p300 $\Delta \mathrm{C}-820$ predominantly localized to discrete punctate regions of the nucleus ("speckles") in transfected fibroblasts. This speckled localization of p300 $\Delta$ C-820 is similar to the staining seen with wildtype p300 and p300 $\Delta \mathrm{C}-1087$ (from RC-K8 cells), but is distinct from the overall nuclear DNA staining seen with DAPI.

We have previously shown that wild-type p300 can enhance the ability of transcription factor REL to activate a multimeric $\mathrm{kB}$-site reporter gene, whereas $\mathrm{p} 300 \Delta \mathrm{C}-1087$ cannot [18]. In more extensive studies, we now find that high amounts of p300 $\Delta \mathrm{C}-820$ and p300 $\Delta \mathrm{C}-1087$ can weakly enhance transactivation by REL. Consistent with previous results [18], wild-type p300 enhanced the ability of REL to activate the $\mathrm{kB}$-site reporter in A293 cells by approximately 2.5 -fold (Figure 2c). In contrast, p300 $\Delta \mathrm{C}$ 820 and p300 $\Delta$ C-1087 enhanced REL-dependent transactivation, on average, by only 1.6- and 1.4-fold, respectively (Figure 2c). To further assess the ability of these C-terminally truncated mutants to enhance REL-dependent transactivation, we co-transfected a constant amount of 

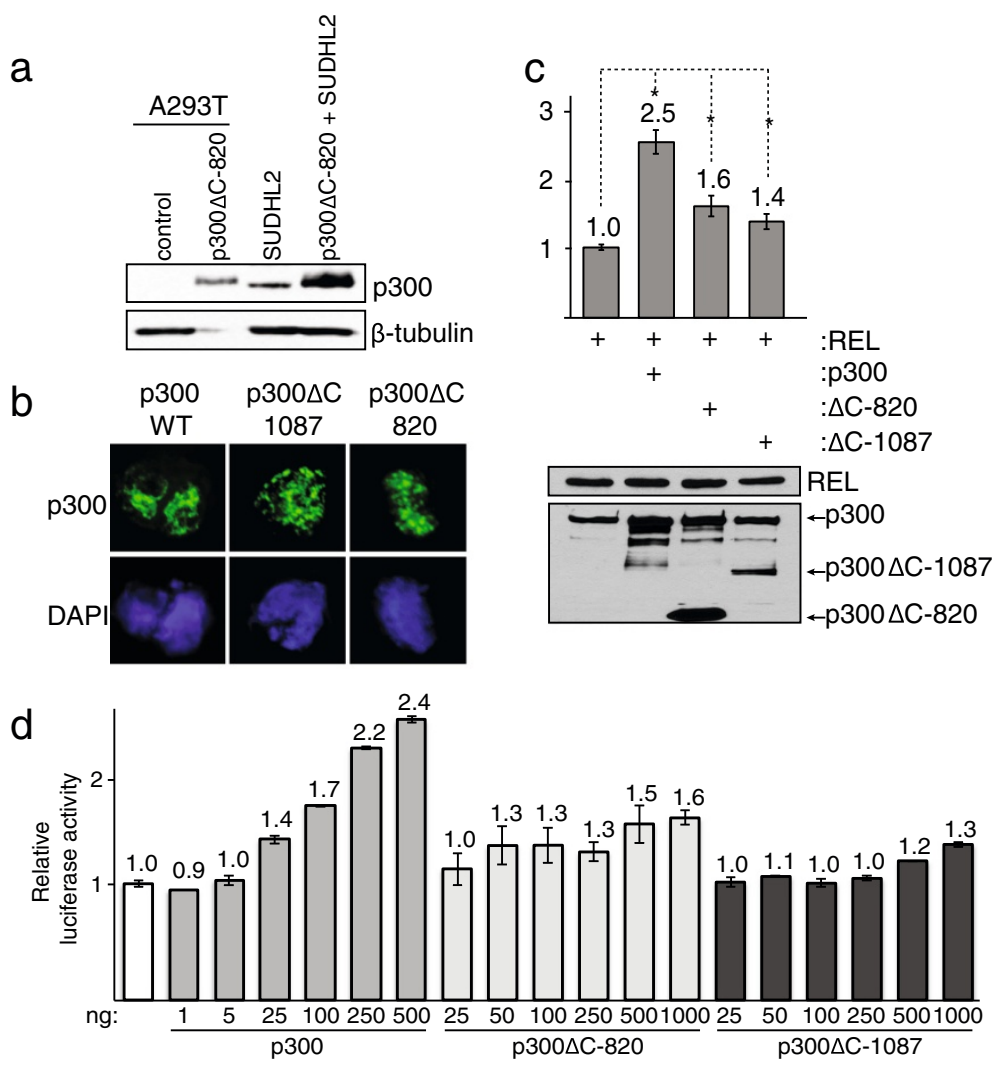

Figure 2 p300 $\Delta$ C-820 localizes to the nucleus, but only weakly enhances REL transactivation. (a) Anti-p300 Western blotting was performed on extracts from control A293T cells, p300 $\mathrm{C}$-820-transfected A293T cells, and SUDHL2 cells. Twenty-five $\mu \mathrm{g}$ of control A293T and SUDHL2 total protein and $30 \mathrm{ng}$ of p300 $\mathrm{C}$-820-transfected A293T total protein were loaded. p300 $\mathrm{C}$-820-transfected A293T and SUDHL2 extracts were loaded together in

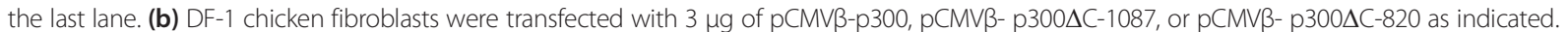
Indirect immunofluorescence was performed using a primary anti-p300 antiserum and a FITC-conjugated anti-rabbit secondary antibody (top row). Nuclei were visualized by DAPI staining (bottom row). (c) A293 cells were co-transfected with $0.5 \mu \mathrm{g}$ of pcDNA-REL along with $0.5 \mu \mathrm{g}$ of $p C M V \beta-p 300, p C M V \beta-p 300 \Delta C-1087$, or $p C M V \beta-p 300 \Delta C-820$ as indicated. Western blotting shows relative p300 and REL expression in transfected cells (bottom panel). Luciferase and $\beta$-galactosidase activities were determined, and values were normalized to control transfections (1.0, top panel). Error bars represent standard error of the mean. Asterisks represent p-value $<0.05$ for the difference between the indicated value and the control value (1.0) in a one-tailed t-test. (d) A293 cells were co-transfected with $0.5 \mu \mathrm{g}$ of pcDNA-REL and the indicated amounts of pCMV $\beta$-p300, pCMV $\beta$-p300 $\Delta C$-820, or pCMV $\beta-p 300 \Delta C$-1087. Luciferase and $\beta$-galactosidase activities were determined, and values were normalized to REL-alone control transfections as indicated (1.0, white bar). Total DNA within each experiment was kept constant by the addition of empty pcDNA3.1 vector. For all reporter assays, values are the averages of at least three experiments, each performed with duplicate or triplicate samples. Error bars represent standard error of the mean.

REL plasmid with increasing amounts of either p300 $\Delta \mathrm{C}$ 820 or p300 $\Delta \mathrm{C}-1087$ expression plasmids and measured transcriptional activation of the $\mathrm{kB}$-site reporter. Like wild-type p300, both p300 $\Delta$ C-820 and p300 $\Delta$ C-1087 enhanced REL-dependent transactivation in a generally dose-dependent manner (Figure 2d). However, both p300 mutants enhanced transcription to a lesser extent than an equimolar amount of wild-type p300 (e.g., $500 \mathrm{ng}$ of p300 $\Delta$ C-820 plasmid enhanced REL-dependent transactivation by 1.5 -fold, whereas 500 ng of wild-type p300 plasmid resulted in a 2.4-fold enhancement). Together, these results demonstrate that both p300 $\Delta \mathrm{C}-820$ and p300 $\Delta \mathrm{C}$ 1087 can enter the nucleus and function as relatively weak coactivators for REL-dependent transactivation.

\section{p300 $\triangle$ C-820 interacts with REL transactivation domain} sequences in vitro and in vivo

We have previously shown that $\mathrm{p} 300 \Delta \mathrm{C}-1087$ retains the ability to interact with transcription factor REL in vitro and in RC-K8 cells, and that this interaction primarily occurs via the $\mathrm{C}$-terminal transactivation domain (TAD) of REL [10]. To determine whether p300 $\Delta$ C-820 also has the ability to interact with REL, a pull-down assay was performed using a GST-REL-TAD fusion protein and wholecell extracts from SUDHL2 cells. Anti-p300 Western blotting showed that GST-REL-TAD specifically pulled down p300 $\Delta$ C-820 (Figure 3a). As a control, GST-RELTAD was incubated with whole-cell extracts from A293 cells, where it was able to pull down endogenous wild- 


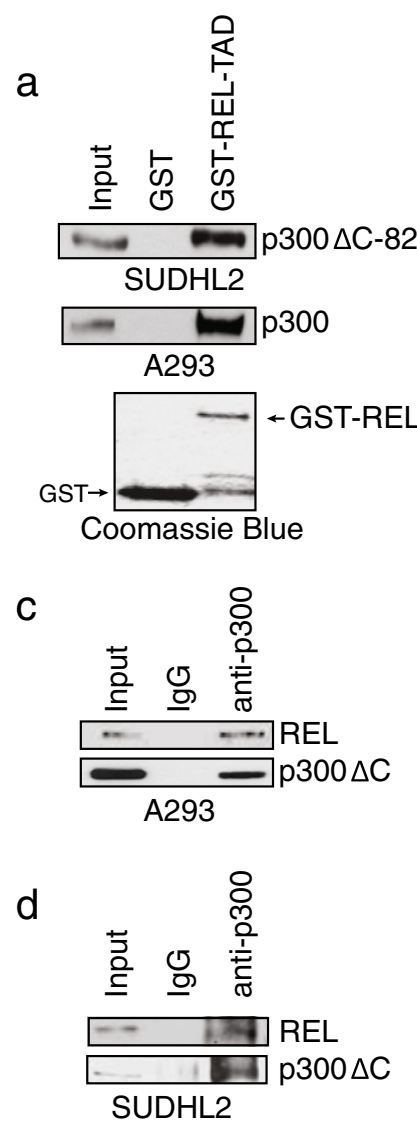

b
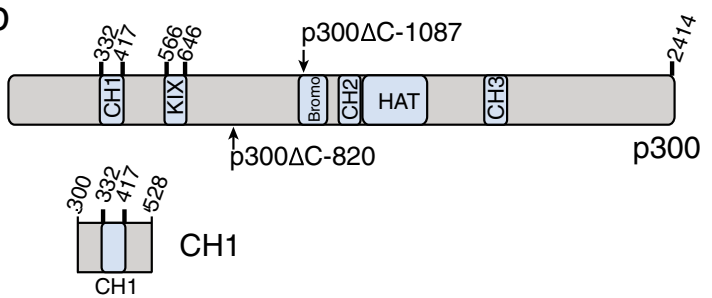

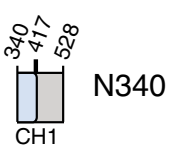

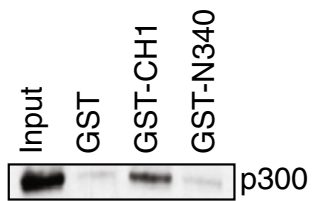

SUDHL2

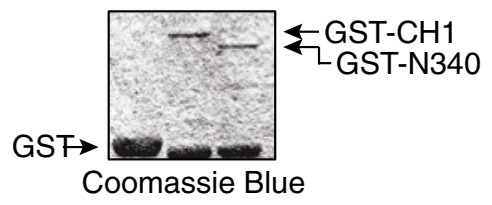

Coomassie Blue

Figure 3 p300 $\mathrm{CC}-820$ interacts with REL in vitro and in vivo. (a) A GST-REL-TAD (aa 324-587) pulldown was performed on whole-cell extracts from SUDHL2 (p300 $\mathrm{C}$-820, top panel) or A293 cells (wild-type 300, middle panel). Bound proteins were subjected to anti-p300 Western blotting to detect p300 $\mathrm{C}$-820 or WT p300, as indicated. (b) GST-p300 pulldown of endogenous REL from SUDHL2 whole-cell extracts. Bound proteins were subjected to anti-REL Western blotting. The structure of wild-type p300 is shown and structures of GST-p300 mutants used are indicated. (c) Nuclear extracts of A293 cells co-transfected with p300 $\mathrm{C}$-820 and REL were immunoprecipitated with normal rabbit lgG or anti-p300 antiserum. Immunoprecipitates were subjected to anti-REL or anti-p300 Western blotting, as indicated. One percent (3 $\mu \mathrm{g}$ ) of the nuclear extract used for immunoprecipitation was included as an input for the anti-REL blot and 10\% (30 $\mathrm{\mu g})$ of the nuclear extract was used as input for the anti-p300 blot. (d) Nuclear extracts of SUDHL2 cells were immunoprecipitation with normal rabbit lgG or anti-p300 antiserum. Immunoprecipitates were subjected to anti-REL or anti-p300 Western blotting, as indicated. Ten percent $(25 \mathrm{\mu g})$ of the nuclear extract used for immunoprecipitate was included as an input for the anti-REL blot and 30\% (75 $\mu \mathrm{g})$ of the nuclear extract was used as input for the anti-p300 blot. Coomassie Blue staining was performed on 5\% of GST or GST-fusion protein used in the pulldowns (a, b lower panels).

type p300 protein (Figure 3a). Moreover, a GST-p300 fusion protein containing the $\mathrm{CH} 1$ protein interaction domain (aa 300-528, retained in p300 $\Delta$ C-820) could pulldown REL from SUDHL2 whole-cell extracts (Figure 3b). This ability to pull-down REL was lost when a smaller $\mathrm{CH} 1$ region was used (aa 340-528) (Figure 3b), indicating that the entire $\mathrm{CH} 1$ domain of $\mathrm{p} 300$ is required for efficient binding to REL.

To determine whether $\mathrm{p} 300 \Delta \mathrm{C}-820$ retains the ability to interact with REL in vivo, we performed an anti-p300 immunoprecipitation from A293 cells co-transfected with expression plasmids for p300 $\Delta \mathrm{C}-820$ and REL. Anti-REL Western blotting of an anti-p300 immunoprecipitate demonstrated that REL can interact with p300 $\Delta$ C-820, at least when overexpressed in a non-lymphoid cell type (Figure 3c). To determine whether endogenous p300 $\Delta \mathrm{C}$ 820 and REL interact in SUDHL2 cells, we performed an anti-p300 immunoprecipitation on nuclear extracts. Anti-REL Western blotting of the anti-p300 immunoprecipitate demonstrated that REL is also present, indicating that REL and p300 $\Delta$ C-820 interact in SUDHL2 cells (Figure 3d).

\section{Knockdown of $\mathrm{p} 300 \Delta \mathrm{C}-820$ reduces the growth of SUDHL2 cells}

To determine whether $\mathrm{p} 300 \Delta \mathrm{C}-820$ contributes to the growth of SUDHL2 cells (which contain no wild-type EP300 allele), we first knocked down expression of 
p300 $\Delta$ C-820 in these cells with a retroviral vector containing a short hairpin RNA (shRNA) that has been previously shown to knock down expression of wild-type p300 [26] and p300 $\Delta$ C-1087 [18]. Western blotting showed that $\mathrm{p} 300 \Delta \mathrm{C}-820$ expression was reduced by approximately $67 \%$ in a pool of SUDHL2 cells expressing p300 shRNA as compared to SUDHL2 cells expressing a control, nontargeting shRNA (Figure 4a). We next compared the proliferation of SUDHL2 cells expressing p300 shRNA and control shRNA by counting cells over the course of four days. Knockdown of p300 $\Delta$ C-820 reduced the proliferation of SUDHL2 in liquid medium (Figure 4b). In addition, SUDHL2 cells with reduced expression of p300 $\Delta$ C-820 formed approximately 8-fold fewer colonies in soft agar than control SUDHL2 cells (Figure 4c). Thus, p300 $\Delta$ C-820 appears to contribute to in vitro growth properties of SUDHL2 cells.

\section{p300 $\Delta \mathrm{C}-1087$ suppresses the expression of NF-кB-regulated genes encoding A20 and ІкBa}

Previous results have shown that several REL/NF- $\mathrm{B}$ target genes are highly expressed in RC-K8 cells [27]. Because REL and p300 $\Delta \mathrm{C}-1087$ interact in RC-K8 cells [10], we sought to determine whether knockdown of p300 $\Delta$ C-1087 would affect expression of some known REL-regulated genes in RC-K8 cells. Therefore, qPCR was performed to compare mRNA levels of seven such genes (A20, BCL2A1, CCR7, NFKBIA [encoding I $\mathrm{B} \alpha \alpha$ ], $L T A, T N F, T R A F 1)$ in RC-K8 cells expressing p300 shRNA to control cells (Figure 4d). First we confirmed by Western blotting that p300 $\Delta \mathrm{C}-1087$ expression was reduced in RC-K8 cells expressing p300 shRNA as compared to RC-K8 cells expressing a control, non-targeting shRNA (Figure 4e, top panel). As shown in Figure 4d, expression of A20, CCR7, NFKBIA, TRAF1, and TNF $\alpha$ mRNAs was significantly increased $(1.1$ - to 1.5 -fold; p $<0.05)$ in p300 knockdown cells, relative to control RC-K8 cells. Expression of $A 1$ and $L T A$ were not significantly increased in $\mathrm{RC}-\mathrm{K} 8$ cells expressing p300 shRNA.

Extracts from RC-K8 cells with knockdown of p300 $\Delta \mathrm{C}$ 1087 were next subjected to anti-A20 and anti-IkB $\alpha$ Western blotting to determine whether the increases in mRNA seen in these cells resulted in increases in protein levels. As shown in Figure 4e, A20 and IкB $\alpha$ protein levels were increased in RC-K8 cells expressing p300 shRNA. $\beta$-tubulin expression was not affected by p300 $\Delta C-1087$ knockdown.

We then sought to determine whether the p300 $\Delta \mathrm{C}$ 1087 protein is located at the $A 20$ promoter in $\mathrm{RC}-\mathrm{K} 8$ cells. Therefore, we performed a ChIP assay in which p300 $\Delta$ C-1087 was immunoprecipitated from RC-K8 cell nuclei and, after reversing crosslinks, qPCR was performed using primers surrounding the $\mathrm{kB}$ sites of the A20 promoter. As shown in Figure 4f, A20 promoter sequences were enriched by approximately four-fold (as compared to the IgG control) in an anti-p300 $\Delta$ C-1087 immonoprecipitate from $\mathrm{RC}-\mathrm{K} 8$ cells.

The expression of p300 $\Delta \mathrm{C}-1087$ is thus associated with a reduction in $\mathrm{A} 20$ and $\mathrm{I}_{\kappa} \mathrm{B} \alpha$ expression at both the mRNA and protein levels. Furthermore, p300 $\Delta$ C-1087 can be found at the $A 20$ promoter, suggesting that p300 $\Delta$ C-1087 has an inhibitory effect on the expression of $A 20$. This analysis was done on RC-K8 cells, rather than SUDHL2 cells, because SUDHL2 cells express a mutant form of A20 protein that is unstable and difficult to detect [28].

\section{Wild-type p300 expression may contribute to overall histone $\mathrm{H} 3$ acetylation in B-cell lymphoma}

Because DLBCL cell lines expressing C-terminally truncated, HAT-deficient p300 proteins do not express detectable amounts of wild-type p300, we next asked whether there was any reduction in overall histone acetylation in cell lines lacking wild-type p300 among a small panel of B-lymphoma cell lines. To do this, we isolated histones from six B-lymphoma cell lines that express varying levels of wild-type p300, from RC-K8 and SUDHL2 (which express no detectable wild-type p300 protein), and from Karpas422 cells (which express detectable wild-type p300 but no detectable CBP [5] [data not shown]), and then used a mass spectrometry-based approach to quantify the degree of acetylation of six lysine residues on histone $\mathrm{H} 3$. The value obtained for each lysine residue represents the fraction of that residue that was acetylated relative to the total amount of each residue that was acetylated plus unmodified (Figure 5, Additional files 2 and 3). Acetylation of H3K9, K56, and $\mathrm{K} 64$ was low and sometimes undetectable in all nine cell lines. In contrast, acetylation of H3K14, K18, and K23 was within a detectable range and varied among the different cell lines. Cell lines with reduced wild-type p300 or CBP (i.e., RC-K8, SUDHL2, and Karpas422, indicated by red diamonds) had average or below average levels of H3K14 and H3K18 acetylation (mean and 95\% CIs were H3K14 $(0.058 \pm 0.091)$ and H3K18 (0.012 \pm $0.014)$, as compared to the broad range of H3K14 and H3K18 acetylation values found in cell lines with detectable levels of full-length p300 and CBP (H3K14, mean $0.252 \pm$ 0.141 , H3K18, mean $0.030 \pm 0.010$ ) (i.e., Farage, Pfeiffer, BJAB, Ramos, SUDHL6, and SUDHL8, indicated by blue circles) (Figure 5, Additional file 2). In contrast, cell lines lacking detectable wild-type p300 or CBP (i.e., SUDHL2, RC-K8, and Karpas422) did not have below average levels of H3K23 acetylation (mean $0.231 \pm$ 0.039 ), relative to the broad range of acetylation values exhibited by cell lines with detectable levels of fulllength p300 and CBP (mean $0.158 \pm 0.061$ ). 

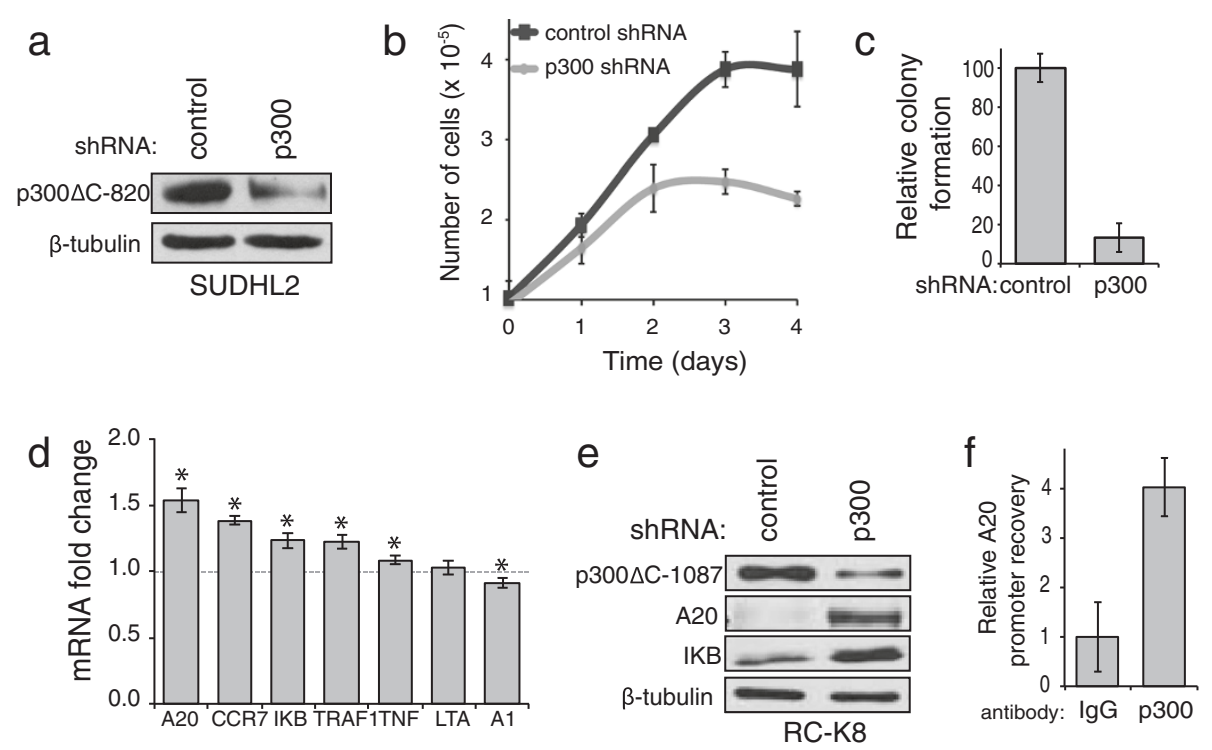

Figure 4 Knockdown of $\mathrm{p} 300 \Delta$ C reduces proliferation of SUDHL2 cells and increases A20 and IKBa expression in RC-K8 cells. (a) Anti-p300 Western blotting was performed on whole-cell extracts from SUDHL2 cells expressing p300 shRNA or control shRNA. Anti- $\beta$-tubulin Western blotting is a loading control. (b) $10^{5} \mathrm{SUDHL} 2$ cells expressing p300 shRNA or control shRNA were plated in $500 \mu \mathrm{LPPMI} / 10 \% \mathrm{FBS}$ in 16-mm wells. On each day, three wells of each cell type were counted. (c) Soft agar colony assays were performed using SUDHL2 cells expressing p300 shRNA or control shRNA. Results are averages of three experiments performed with triplicate plates containing 2000 or 5000 cells. Colony numbers are normalized to the number of colonies formed by SUDHL2 cells expressing control shRNA (100). Error bars represent standard deviation. (d) Reverse transcribed total RNA from RC-K8 cells expressing p300 shRNA or a control shRNA was subjected to real-time qPCR using gene-specific primers. mRNA expression values from RC-K8 cells expressing p300 shRNA were compared to values from RC-K8 cells expressing control shRNA to determine the fold change in expression. Error bars represent standard error of the mean. Asterisks indicate $p$-values $<0.05$ for the difference in mRNA levels relative to control cells ( $=1.0)$ using a two-tailed t test. (e) Anti-p300, anti-A20, and anti-IKBa Western blotting was performed on whole-cell extracts from RC-K8 cells expressing p300 shRNA or control shRNA. Anti- $\beta$-tubulin Western blotting is a loading control. (f) RC-K8 cells were subjected to crosslinking with formaldehyde and extracts from isolated nuclei were then immunoprecipitated using normal rabbit lgG or anti-p300 antiserum. The crosslinks were reversed and DNA in immunoprecipitates was subjected to qPCR using primers spanning the A20 promoter region. Relative A20 promoter PCR product was normalized to the lgG control (1.0). Error bars represent the standard error of the mean.

\section{Discussion}

In this report, we have characterized molecular properties of the HAT-deficient p300 $\Delta \mathrm{C}$-820 protein from the human DLBCL cell line SUDHL2. This is only the second truncated p300 mutant that has been functionally characterized in a human DLBCL cell line $[10,18]$. We show that p300 $\Delta$ C-820 is the only form of p300 protein expressed in SUDHL2 cells and that p300 $\Delta \mathrm{C}-820$ contributes to SUDHL2 cell growth, as knockdown of p300 $\Delta$ C-820 expression compromised the liquid media and soft agar growth of SUDHL2 cells. Like wild-type p300, p300 $\Delta$ C820 localizes to the nucleus and can interact with NF- $\mathrm{KB}$ family member REL, but $\mathrm{p} 300 \Delta \mathrm{C}-820$ has a reduced ability to enhance REL-dependent transactivation in reporter assays. As such, p300 $\Delta \mathrm{C}$ mutants have the potential to attenuate expression of transcription factor-specific target genes by preventing the interaction of transcription factors with other functionally intact coactivators. Indeed, knockdown of $\mathrm{p} 300 \Delta \mathrm{C}-1087$ in RC-K8 cells resulted in increased expression of NF-kB target genes $A 20, C C R 7$, NFKBIA, TRAF1 and TNF $\alpha$, as well as an increase in $\mathrm{A} 20$ and $\mathrm{I} \kappa \mathrm{B} \alpha$ protein expression. Finally, the $\mathrm{RC}-\mathrm{K} 8$ and SUDHL2 cell lines, which have reduced expression of wild-type p300, had generally reduced levels of acetylation of histone $\mathrm{H} 3 \mathrm{~K} 14$ and $\mathrm{K} 18$ among a panel of B-lymphoma cell lines.

Like wild-type $\mathrm{p} 300$ and the $\mathrm{p} 300 \Delta \mathrm{C}-1087$ protein from $\mathrm{RC}-\mathrm{K} 8$ cells, p300 $\Delta \mathrm{C}-820$ showed a punctate pattern of nuclear staining by immunofluorescence, which has been associated with sites of active transcription for wild-type p300 [29]. Using reporter assays, p300 $\Delta$ C-820 and $\mathrm{p} 300 \Delta \mathrm{C}-1087$ are both weak transcriptional coactivators for REL in A293 cells (Figures 2c,d). Because p300 acts as a transcriptional coactivator through both HAT-dependent and HAT-independent mechanisms, the limited coactivator activity retained by these two C-terminally truncated p300 mutants is likely a function of protein-protein interactions that result in recruitment of transcriptional machinery to the transcription start site (i.e., HAT-independent activities). In some promoter contexts, such HAT-independent activities may suffice to maintain normal p300 function. For example, it has been shown that HAT deletion mutants of p300 can still enhance MyoD-dependent transcription, possibly by 


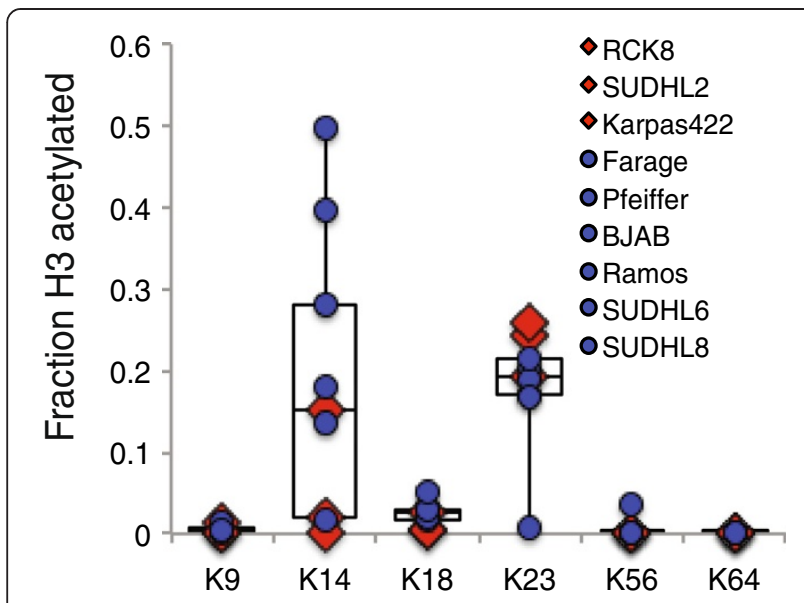

Figure 5 Total histone $\mathrm{H} 3$ lysine acetylation profile in DLBCL cell lines. Total histones were extracted from the indicated cell lines, were trypsinzed, and subjected to mass-spec analysis. For each $\mathrm{H} 3$ lysine residue, the amount of the acetylated lysine residue was measured relative to total amount of acetylated plus unmodified residue. Cell lines indicated by red diamonds express undetectable levels of wild-type p300 (RC-K8, SUDHL2) or wild-type CBP (Karpas422) by Western blotting. Cell lines indicated by blue circles express detectable levels of p300 and CBP by Western blotting. A box plot of the fraction of acetylated lysine residue out of total acetylated plus unmodified $\mathrm{H} 3$ was plotted for each lysine residue. For cell lines indicated by red diamonds, the mean values and $95 \% \mathrm{Cls}$ for H3 lysine acetylation were as follows: H3K14 (0.058 \pm 0.091$),$ H3K18 $(0.012 \pm 0.014)$, and H3K23 $(0.231 \pm 0.039)$. For cell lines indicated by blue circles, the means and $95 \% \mathrm{Cls}$ were H3K14 (0.252 \pm 0.141$)$, H3K18 $(0.030 \pm 0.010)$, and H3K23 (0.158 \pm 0.061$)$.

stabilizing a ternary complex between MyoD and other coactivators [30]. Thus, it is likely that HAT-deficient p300 proteins have altered p300 activity in some settings (e.g., REL-dependent transactivation), but not in others (e.g., MyoD-dependent transactivation). Therefore, we suggest that cells expressing mutant p300 proteins are distinct from p300-null cells.

$A 20$ is a tumor suppressor and a target gene of NF- $\mathrm{kB}$, is biallelically inactivated in approximately $30 \%$ of DLBCL, and is mutated in the SUDHL2 and RC-K8 cell lines $[28,31,32]$. Knockdown of p300 $\Delta \mathrm{C}-1087$ resulted in increased expression of A20 in RC-K8 cells (Figures 4d,e). That observation and the presence of $\mathrm{p} 300 \Delta \mathrm{C}-1087$ at the $A 20$ promoter (Figure 4f) suggest that $\mathrm{p} 300 \Delta \mathrm{C}-1087$ directly reduces $A 20$ gene expression in RC-K8 cells, leading to reduced A20 protein. Reduced A20 protein activity appears to be essential for RC-K8 and SUDHL2 survival, as re-expression of wild-type A20 induces apoptosis in both cell types [28]. Therefore, it appears that A20 activity is reduced in SUDHL2 and RC-K8 cells by both mutation [28] and transcriptional repression mediated by mutant $\mathrm{p} 300$.

Knockdown of p300 $\Delta \mathrm{C}-1087$ in RC-K8 cells also resulted in increased ІкB $\alpha$ expression (Figures 4e,f). We have previously shown that $\mathrm{RC}-\mathrm{K} 8$ cells have inactivating mutations in three of four copies of the NFKBIA gene, express little wild-type IKB $\alpha$ protein, and consequently show high levels of both nuclear REL DNA-binding activity and REL target gene expression [27]. Forced expression of wild-type IKB $\alpha$ protein slows the growth of RC-K8 cells, presumably due to inhibition of REL [27].

Taken together, these results suggest that C-terminally truncated p300 proteins contribute to the oncogenic state in SUDHL2 and RC-K8 cell lines, at least in part, by reducing expression of both $\mathrm{A} 20$ and $\mathrm{I}_{\kappa} \mathrm{B} \alpha$, which allows for tolerable and optimal levels of nuclear NF- $\mathrm{kB}$ activity that promote cell growth. Indeed, both cell lines belong to the $\mathrm{ABC}$-subtype of DLBCL, which is characterized by constitutive NF- $\kappa B$ activity and sensitivity to NF- $\kappa B$ inhibitors [33]. Overall, we propose that the high levels of nuclear REL-driven transactivation of target genes that is unleashed by mutations in the REL/NF- $\kappa B$ inhibitors A20 and IKB $\alpha$ in RC-K8 and SUDHL2 cells is tempered by expression of $\mathrm{p} 300 \Delta \mathrm{C}$ proteins, which act as muted REL coactivators. The model that moderate, chronic increases in REL-driven target gene expression are optimal for B-lymphoid cell transformation is reminiscent of the mutation-driven activation of the lymphoid cell-specific oncoprotein v-Rel, which is a chronic low level activator of target gene expression as compared to c-Rel [34].

The $\mathrm{CH} 1$ domain of $\mathrm{p} 300$ is retained in both $\mathrm{p} 300 \Delta \mathrm{C}$ 1087 and $\mathrm{p} 300 \Delta \mathrm{C}-820$, and is required for the interaction of p300 with REL (Figure 3b). Thus, the $\mathrm{CH} 1$ domain and interaction with REL may be important for the growthpromoting activity of truncated p300 proteins in DLBCL. In support of this hypothesis, Kimbrel et al. [21] used a mouse in vivo reconstitution system to show that expression of a HAT domain mutant of p300 increased the proliferative potential of hematopoietic stem and progenitors cells, whereas expression of a $\mathrm{CH} 1$ domain mutant resulted in severe defects in hematopoiesis.

We have found that DLBCL cell lines with reduced expression of wild-type p300 generally have low levels of H3K14 and H3K18 acetylation (Figure 5, Additional files 2 and 3). It has been shown that p300 and CBP are able to acetylate H3K14 and H3K18 in vitro and that p300 and CBP are required for H3K18 acetylation in vivo [35,36]. Additionally, hypoacetylation of H3K18 by inhibition of p300 and CBP stimulates cell cycling in quiescent human cells and has been associated with recurrence of lowgrade prostate cancer in patient studies [36-38]. Developmental studies in mice have shown that acetylation of H3K14 is associated with gene activation [39], suggesting that its reduction in RC-K8 and SUDHL2 cells prevents expression of target genes specifically related to growth inhibition and/or apoptosis. Consistent with this hypothesis, H3K14 acetylation at the promoter of the cell cycle inhibitor p21 is upregulated 10-fold in response to treatment with the topoisomerase II inhibitor doxorubicin, 
and is required for stress-induced cell-cycle arrest in human cancer cell lines [40]. We suggest that expression of truncated p300 and the associated reduction of wild-type p300 is one mechanism that can lead to reduced acetylation of H3K14 and H3K18, which contributes to DLBCL cell growth. Of note, SUDHL2 and RC-K8 cells are sensitive to apoptosis induced by treatment with two HDAC inhibitors [41].

Our findings contradict a previously published report on the lack of full-length p300 protein in the BJAB, SUDHL8, and Farage DLBCL cell lines [3]. We were able to show that multiple cell line stocks, including ones used in the conflicting report, express easily detectable levels of full-length p300 protein. Thus, we believe that the lack of full-length p300 protein in these three cell lines reported in Pasqualucci et al. [3] was due to a technical error. Northern blotting data reported by Pasqualucci et al. [3] further support our results, in that the BJAB, SUDHL8, and Farage cell lines express detectable levels of full-length p300 mRNA, whereas SUDHL2 cell do not. Moreover, full-length p300 protein expression in BJAB and Farage cells has been reported by several others [7,22-25].

\section{Conclusions}

Based on our continuing studies, we propose that elimination of p300 HAT activity and expression of HAT-deletion p300 mutants both play oncogenic roles in DLBCL. Specifically, the HAT-independent activities retained in the truncated p300 proteins contribute to the proliferation and soft agar growth of certain DLBCL cell lines in vitro. Future studies will be aimed at identifying other pathways and genes in DLBCL cells that are affected by the expression of p300 mutants.

\section{Materials and methods Plasmids}

DNA manipulations were carried out by standard methods [42]. Complete details of subclones and primers used in this study are described in supplementary information and at www.nf-kb.org. GST-p300-CH1 and GST-p300-N340 expression plasmids were kindly provided by Andrew Kung and have been described previously [14]. All recombinant DNA and human cell line work was conducted with BSL-2 level approval of the Boston University Institutional Biosafety Committee (approval number 11-072).

\section{Cell culture}

A293, A293T, BOSC23 human embryonic kidney cells, DF-1 chicken fibroblasts, and RC-K8 cells were cultured in Dulbecco's modified Eagle's medium (DMEM) supplemented with $10 \%$ fetal bovine serum (FBS) (Biologos, Montgomery, IL, USA) as described previously [43]. $B J A B$ cells were cultured in DMEM supplemented with $20 \%$ FBS. SUDHL2, Ramos, and Farage cells were cultured in RPMI supplemented with 10\% FBS. SUDHL8 cells were cultured in RPMI supplemented with $20 \%$ FBS. The human B-lymphoma cell lines are classified as follows: DLBCL (BJAB [3,16,44], Farage [2,45], RC-K8 [8], SUDHL2 [3], SUDHL8 [3,19]), and Burkitt's lymphoma (Ramos).

Transfection of A293, A293T, BOSC23, and DF-1 cells was performed as described previously [18]. For Western blotting and indirect immunofluorescence, cells were processed $48 \mathrm{~h}$ after addition of the transfection mix.

Design of control and EP300 short hairpin RNAs (shRNA), generation of virus stocks, and infections were performed as described previously [18]. Two days after infection, SUDHL2 and RC-K8 cells were selected with $1 \mu \mathrm{g} / \mathrm{ml}$ puromycin (Sigma, St. Louis, MO, USA), respectively, for 2-4 weeks and maintained in puromycin throughout all experiments.

\section{Western blotting and indirect immunofluorescence}

Whole-cell lysates were prepared in AT buffer containing protease inhibitors as described previously [46] and were analyzed by Western blotting according to standard methods [10]. High molecular weight proteins (full-length p300 and CBP) were transferred at $260 \mathrm{~mA}$ for $2.5 \mathrm{~h}$ at $4^{\circ} \mathrm{C}$ using a modified large-protein transfer buffer (20 $\mathrm{mM}$ Tris, $150 \mathrm{mM}$ glycine, $0.05 \%$ SDS, $10 \%$ methanol) as described previously [10]. Western blots were quantified using ImageJ software [47].

The following antisera were used: rabbit anti-p300 (1:200; anti-N-terminal, sc-584, Santa Cruz Biotechnology, Santa Cruz, CA, USA), rabbit anti-REL (1:200; obtained from Nancy Rice [43]), mouse anti-CBP (1:200; sc-7300, Santa Cruz Biotechnology), mouse anti-A20 (1:200, 550859, BD Pharmingen, Franklin Lakes, NJ, USA), mouse antiIкB $\alpha$ (1:1000, 4814, Cell Signaling Technology), and rabbit anti- $\beta$-tubulin (1:500; sc-9104, Santa Cruz Biotechnology).

Indirect immunofluorescence was performed as described previously $[18,43]$ using anti-p300 (1:50; sc-584, Santa Cruz Biotechnology) primary antibody and fluorescein isothiocyanate (FITC)-conjugated goat anti-rabbit IgG (1:80; Sigma) secondary antibody. Nuclei were also stained with 4',6-diamidino-2-phenylindole (DAPI). Cells were visualized using a fluorescent microscope (Olympus FLUOVIEW Laser Scanner Microscope BX 50, Center Valley, PA, USA).

\section{Co-immunoprecipitation}

For co-immunoprecipitation of overexpressed proteins, A293 cells in $100-\mathrm{mm}$ dishes were co-transfected with $10 \mu \mathrm{g}$ pcDNA-Flag-REL and $10 \mu \mathrm{g}$ pCMV $\beta-\mathrm{p} 300 \Delta \mathrm{C}$ 820. Two days later, nuclear extracts were prepared using a Nuclear Complex Co-IP Kit (cat no. 54001, Active Motif, Carlsbad, CA, USA) according to the manufacturer's instructions. Nuclear extracts containing $300 \mu \mathrm{g}$ of protein 
were incubated with anti-p300 antiserum or rabbit preimmune serum for $3 \mathrm{~h}$ at $4^{\circ} \mathrm{C} .100 \mu \mathrm{l}$ of a $50 \%$ slurry of Protein A Sepharose CL-4B (GE Healthcare Life Sciences, Pittsburgh, PA, USA) was added and the sample was incubated for an additional $1 \mathrm{~h}$ at $4^{\circ} \mathrm{C}$. The beads were then washed in PBS and proteins were eluted by heating at $95^{\circ} \mathrm{C}$ in SDS sample buffer. Proteins were electrophoresed on a 7.5\% SDS-polyacrylamide gel and transferred to a nitrocellulose membrane as described above. One percent of the amount of nuclear extract used for one immunoprecipitation $(3 \mu \mathrm{g})$ was included on the gel as an input lane. The membranes were then subjected to anti-REL Western blotting.

Co-immunoprecipitation of endogenous REL and p300 $\Delta \mathrm{C}$ 820 in SUDHL2 cells was performed using the Nuclear Complex Co-IP Kit as described by the manufacturer (cat. no. 54001, Active Motif). Three micrograms of normal rabbit IgG (sc-2027, Santa Cruz Biotechnology) or anti-p300 antiserum (sc-584, Santa Cruz Biotechnology) was incubated with $250 \mu \mathrm{g}$ of nuclear extract in IP Low Buffer (Active Motif) for $3 \mathrm{~h}$ at $4{ }^{\circ} \mathrm{C}$. $50 \mu \mathrm{l}$ of a $50 \%$ slurry of Protein A Sepharose CL-4B (GE Healthcare Life Sciences) was added, and samples were incubated for an additional $3 \mathrm{~h}$. Beads were then washed with IP Low Buffer and proteins were eluted by heating at $95^{\circ} \mathrm{C}$ in SDS sample buffer. Proteins were electrophoresed on a 6\% SDS-polyacrylamide gel and transferred to a nitrocellulose membrane as described above. Ten percent of the amount of nuclear extract used for one immunoprecipitation $(25 \mu \mathrm{g})$ was included on the gel as an input lane. The membranes were then subjected to anti-REL or antip300 Western blotting.

\section{GST pulldown assays}

GST pulldown assays followed by Western blotting were performed as described previously [10]. One percent of the amount of extract used for each pulldown $(30 \mu \mathrm{g})$ was included on the gel as an input lane. The membrane was then subjected to anti-p300 or anti-REL Western blotting.

\section{Luciferase reporter assays}

Luciferase reporter assays were performed using the Luciferase Assay System (Promega, Madison, WI, USA) as described previously [18]. A293 cells in 35-mm plates were transfected with $0.5 \mu \mathrm{g}$ of reporter plasmid pGL2$3 \times-\mathrm{kB}$-luciferase and $0.5 \mu \mathrm{g}$ of normalization plasmid pRSV-ßgal. Cells were co-transfected with $0.5 \mu \mathrm{g}$ of pcDNA-REL or pcDNA3.1 vector alone, along with $0.5 \mu \mathrm{g}$ of $\mathrm{pCMV} \beta-\mathrm{p} 300, \mathrm{pCMV} \beta-\mathrm{p} 300 \Delta \mathrm{C}$, or vector alone. In titration experiments (Figure $2 \mathrm{~d}$ ), cells were transfected with $0.5 \mu \mathrm{g}$ of pcDNA-REL, and increasing amounts of $p C M V \beta-p 300$, pCMV $\beta-p 300 \Delta C-1087$, or pCMV $\beta-p 300 \Delta C-820$. Increasing amounts of each p300 plasmid were titrated in until luciferase activity reached a plateau. For all luciferase reporter assay experiments, total DNA per transfection was kept constant by including varying amounts of pcDNA3.1 vector. Luciferase and $\beta$-galactosidase activities were determined, and values were normalized to the relevant vector control (1.0).

Statistical analyses were performed using a paired onetailed $\mathrm{t}$-test and $\mathrm{p}<0.05$ was considered significant.

\section{Cell proliferation and soft agar assays}

Cell proliferation and soft agar colony assays were performed as described previously $[18,48]$. Equal numbers (2000 and 5000) of SUDHL2 cells expressing the indicated shRNA were placed in soft agar containing RPMI with 20\% FBS and 0.3\% Bacto Agar (Difco, Franklin Lakes, NJ, USA), and plates were incubated at $37^{\circ} \mathrm{C}$ in a humid incubator with $5 \% \mathrm{CO}_{2}$. Macroscopic colonies were counted 14 days after plating.

\section{Chromatin immunoprecipitation assays and QPCR}

For ChIP assays, approximately $10^{8} \mathrm{RC}-\mathrm{K} 8$ cells were fixed with 3\% formaldehyde for $20 \mathrm{~min}$ at room temperature. Cells were then rinsed three times with ice-cold PBS and nuclear lysate was prepared as described previously [49]. Samples containing $350 \mu \mathrm{g}$ of protein were then incubated at $4^{\circ} \mathrm{C}$ overnight with either rabbit anti-p300 antiserum or pre-immune serum. The next day, $50 \mu \mathrm{l}$ of a $50 \%$ slurry of protein $\mathrm{A}$ beads was added and the reaction was incubated for $3 \mathrm{~h}$ at $4^{\circ} \mathrm{C}$. Beads were washed with RIPA buffer (50 $\mathrm{mM}$ Tris- $\mathrm{HCl} \mathrm{pH}$ 7.2, $150 \mathrm{mM} \mathrm{NaCl}, 1 \%$ deoxycholic acid, $1 \%$ Triton X-100, $0.1 \%$ SDS) and then TE supplemented with $50 \mathrm{mM} \mathrm{NaCl}$. Beads were eluted in $\mathrm{TE}$ with $2 \%$ SDS for $15 \mathrm{~min}$ at $65^{\circ} \mathrm{C}$. Crosslink reversal and DNA purification were performed as described previously [49]. Purified DNA was then subjected to qPCR using primers to amplify the TNFAIP3 (A20) promoter. PCRs were performed in the ABI Prism 7900HT Sequence Detection System (Applied Biosystems, Foster City, CA, USA) using 40 cycles of $94^{\circ} \mathrm{C}$ for $15 \mathrm{~s}$ and $60^{\circ} \mathrm{C}$ for $1 \mathrm{~min}$. The primers used were 5'-CAGCCCGACCCAGAGAGTCAC and 5'-TTCGTGGCGGGCCAAG [50]. Cycle threshold $\left(\mathrm{C}_{\mathrm{t}}\right)$ values for $\mathrm{p} 300$ were normalized to the pre-immune serum control values (1.0). Error bars represent standard error.

\section{PCR and real-time quantitative PCR}

Two hundred ng of genomic DNA from SUDHL2 cells was subjected to PCR using forward and reverse primers specific for sequences surrounding exon 14 of EP300. The primers used were 5' AGCATAGGCAGGCCCTAGA and 5'- TATGCTTGGGGGAGTATGGT. Sequencing of the amplified fragment was performed by Eurofins MWG Operon (Huntsville, AL, USA).

For qPCR of mRNA, total RNA was first isolated from RC-K8 cells using TRIzol Reagent (Invitrogen, Grand 
Island, NY, USA) according to the manufacturer's protocol. The mRNA was reverse transcribed into cDNA using M-MLV reverse transcriptase (Promega) and random primers (Promega). One thirtieth of the synthesized cDNA was combined with gene-specific primers and Power SYBR Green PCR Master Mix (Applied Biosystems). PCRs were performed as described above. $C_{t}$ values were obtained for each sample and normalized to $C_{t}$ values for GAPDH cDNA amplification $\left(\Delta \mathrm{C}_{\mathrm{t}}\right)$ and then to $\mathrm{C}_{\mathrm{t}}$ values from control shRNA-expressing RC-K8 cells $\left(\Delta \Delta \mathrm{C}_{\mathrm{t}}\right)$ using methods described previously [51]. The fold change in mRNA was normalized to the fold change in GAPDH mRNA expression (1.0) between p300 and control knockdown RC-K8 cells. Primers used were A20: 5' - CGCTCA AGGAAACAGACACA and 5'- CTTCAGGGTCACCA AGGGTA; CCR7: 5'-TGAGGTCACGGACGATTACAT and 5'- GTAGGCCCACGAAACAAATGAT; NFKBIA: 5'- CTCCGAGACTTTCGAGGAAATAC and 5'- GCCATT GTAGTTGGTAGCCTTCA; TRAF1: 5'- TCCTGTGGAA GATCACCAATGT and 5'- GCAGGCACAACTTGTAG CC; TNF: 5'- GAGGCCAAGCCCTGGTATG and 5'- CG GGCCGATTGATCTCAGC; LTA: 5'- CATCTACTTCGT CTACTCCCAGG and 5'-CCCCGTGGTACATCGAGTG; A1: 5'- TACAGGCTGGCTCAGGACTAT and 5'- CGCA ACATTTTGTAGCACTCTG; GAPDH: 5'- TGGTATCG TGGAAGGACTCATGAC and 5'- ATGCCAGTGAGCT TCCCGTTCAGC.

Statistical analyses were performed using a paired twotailed $\mathrm{t}$-test, and $\mathrm{p}<0.05$ was considered significant.

\section{Quantification of histone acetylation via mass spectrometry}

Cell lines were maintained in healthy conditions for several passages before histones were purified using the Active Motif Histone Purification Kit (cat no. 40025) according to the manufacturer's instructions. Concentrations were determined using Nanodrop, $5 \mu \mathrm{g}$ of each sample was chemically propionylated using $1.5 \mu \mathrm{l}$ propionic anhydride, and ammonium hydroxide was used to quickly adjust the $\mathrm{pH}$ to approximately 8.0 [52]. Samples were then incubated at $51^{\circ} \mathrm{C}$ for $1 \mathrm{~h}$ followed by trypsin digestion overnight at $37^{\circ} \mathrm{C}$. The fraction of acetylated to unmodified at a given histone $\mathrm{H} 3$ site was performed as described previously [53]. Means and 95\% confidence intervals of acetylation values for different cell lines were calculated.

\section{Additional files}

Additional file 1: SUDHL2 cells do not have a wild-type EP300 sequence at codon 821. Genomic DNA corresponding to exon 14 of EP300 was sequenced in SUDHL2 cells. Sequencing was performed in the forward (top strand) and reverse (bottom strand) direction. Chromatograms and corresponding nucleotides are shown in the forward (top strand) and reverse (bottom strand) direction. The reported C2856T nonsense mutation at codon 821 [3] is highlighted.

Additional file 2: Relative histone $\mathrm{H} 3$ acetylation profile in DLBCL cell lines. Total histones were extracted from the indicated cell lines. For each $\mathrm{H} 3$ lysine residue, the amount of the acetylated lysine residue is reported relative to total amount of acetylated plus unmodified residue. To generate the relative fraction of acetylated $\mathrm{H} 3$, a single common maximum value and single common minimum value were applied to all lysine residues analyzed, and absolute values (Figure 5) within each residue were distributed proportionally across this normalized range. The relative fraction of acetylated $\mathrm{H} 3$ for all cell lines is shown as a box plot for each lysine residue. Cell lines indicated by red diamonds express undetectable levels of wild-type p300 (RC-K8, SUDHL2) or wild-type CBP (Karpas422) by Western blotting. Cell lines indicated by blue circles express detectable levels of full-length p300 and CBP by Western blotting.

Additional file 3: Fraction of acetylated lysine residue relative to total acetylated plus unmodified residue in Histone H3. Fraction of acetylated lysine residue as determined by mass spectrometry for B-lymphoma cell lines. Values are plotted in Figure 5.

\section{Abbreviations}

aa: Amino acid (s); bp: Base pair; $\mathrm{CH1}$ : Cysteine/histidine-rich 1; Cl: Confidence interval; DLBCL: Diffuse large B-cell lymphoma;

DMEM: Dulbecco's modified Eagle's medium; FBS: Fetal bovine serum; GST: Glutathione S-transferase; HAT: Histone acetyltransferase; PCR: Polymerase chain reaction; PEl: Polyethylenimine; shRNA: Short hairpin RNA; TAD: Transactivation domain.

\section{Competing interests}

The authors declare that they have no competing interests.

\section{Authors' contributions}

LH performed all experiments except for full-length p300 detection in multiple DLBCL isolates (JL-P) and mass-spectrometry analysis of histone $\mathrm{H} 3$ acetylation (RAH, AJA). LH and TDG designed the studies and analyzed and interpreted the data. LH and TDG wrote the manuscript. All authors read and approved the final manuscript.

\section{Acknowledgements}

We thank Drs. Laura Pasqualucci, Leonardo Cerchietti, Ricardo Dalla-Favera, David Thorley-Lawson, Gerald Denis, and Alan Yeo for human B-lymphoma cell lines and helpful discussions. We thank Dr. Andrew L. Kung for GSTtagged p300 expression plasmids and helpful discussions. This work was supported by NIH ARRA supplement CA047763-21S3 (to TDG). LH was supported by NHLBI Hematology training grant T32 HL007501 and NSF GK-12 grant DGE0947950. JLP was supported by NSF-REU grant DBI-085171. RH and AJA were supported by the WW Smith Trust and by a grant from the Pennsylvania Department of Health. The Pennsylvania Department of Health specifically disclaims

responsibility for any analysis, interpretations or conclusions.

\section{Author details}

'Department of Biology, Boston University, 5 Cummington Mall, Boston, MA 02215, USA. ${ }^{2}$ Fox Chase Cancer Center, Philadelphia, PA 19111, USA.

Received: 14 June 2013 Accepted: 5 February 2014

Published: 15 February 2014

\section{References}

1. Morton LM, Wang SS, Devesa SS, Hartge P, Weisenburger DD, Linet MS: Lymphoma incidence patterns by WHO subtype in the United States, 1992-2001. Blood 2006, 107:265-276.

2. Alizadeh AA, Eisen MB, Davis RE, Ma C, Lossos IS, Rosenwald A, Boldrick JC, Sabet H, Tran T, Yu X, Powell Jl, Yang L, Marti GE, Moore T, Hudson J Jr, Lu L, Lewis DB, Tibshirani R, Sherlock G, Chan WC, Greiner TC, Weisenburger DD, Armitage JO, Warnke R, Levy R, Wilson W, Grever MR, Byrd JC, Botstein D, Brown PO, et al: Distinct types of diffuse large B-cell lymphoma identified by gene expression profiling. Nature 2000, 403:503-511.

3. Pasqualucci L, Dominguez-Sola D, Chiarenza A, Fabbri G, Grunn A, Trifonov V, Kasper LH, Lerach S, Tang H, Ma J, Rossi D, Chadburn A, Murty W, Mullighan CG, 
Gaidano G, Rabadan R, Brindle PK, Dalla-Favera R: Inactivating mutations of acetyltransferase genes in B-cell lymphoma. Nature 2011, 471:189-195.

4. Pasqualucci L, Trifonov V, Fabbri G, Ma J, Rossi D, Chiarenza A, Wells VA, Grunn A, Messina M, Elliot O, Chan J, Bhagat G, Chadburn A, Gaidano G, Mullighan CG, Rabadan R, Dalla-Favera R: Analysis of the coding genome of diffuse large B-cell lymphoma. Nat Genet 2011, 43:830-837.

5. Morin RD, Mendez-Lago M, Mungall AJ, Goya R, Mungall KL, Corbett RD, Johnson NA, Severson TM, Chiu R, Field M, Jackman S, Krzywinski M, Scott DW, Trinh DL, Tamura-Wells J, Li S, Firme MR, Rogic S, Griffith M, Chan S, Yakovenko O, Meyer IM, Zhao EY, Smailus D, Moksa M, Chittaranjan S, Rimsza L, Brooks-Wilson A, Spinelli JJ, Ben-Neriah S, et al: Frequent mutation of histone-modifying genes in non-Hodgkin lymphoma. Nature 2011, 476:298-303.

6. Lohr JG, Stojanov P, Lawrence MS, Auclair D, Chapuy B, Sougnez C, Cruz-Gordillo P, Knoechel B, Asmann YW, Slager SL, Novak AJ, Dogan A, Ansell SM, Link BK, Zou L, Gould J, Saksena G, Stransky N, Rangel-Escareno C, Fernandez-Lopez JC, Hidalgo-Miranda A, Melendez-Zajgla J, Hernandez-Lemus E, Schwarz-Cruz Y, Celis A, Imaz-Rosshandler I, Ojesina Al, Jung J, Pedamallu CS, Lander ES, Habermann TM, et al: Discovery and prioritization of somatic mutations in diffuse large B-cell lymphoma (DLBCL) by whole-exome sequencing. Proc Natl Acad Sci U S A 2012, 109:3879-3884.

7. Cerchietti LC, Hatzi K, Caldas-Lopes E, Yang SN, Figueroa ME, Morin RD, Hirst M, Mendez L, Shaknovich R, Cole PA, Bhalla K, Gascoyne RD, Marra M, Chiosis G, Melnick A: BCL6 repression of EP300 in human diffuse large $B$ cell lymphoma cells provides a basis for rational combinatorial therapy. J Clin Invest 2010, 120:4569-4582.

8. Giordano A, Avantaggiati ML: p300 and CBP: partners for life and death. J Cell Physiol 1999, 181:218-230

9. Gerritsen ME, Williams AJ, Neish AS, Moore S, Shi Y, Collins T: CREB-binding protein/p300 are transcriptional coactivators of p65. Proc Natl Acad SC US A 1997, 94:2927-2932.

10. Garbati MR, Alço G, Gilmore TD: Histone acetyltransferase p300 is a coactivator for transcription factor REL and is C-terminally truncated in the human diffuse large B-cell lymphoma cell line RC-K8. Cancer Lett 2010, 291:237-245.

11. Avantaggiati ML, Ogryzko V, Gardner K, Giordano A, Levine AS, Kelly K: Recruitment of p300/CBP in p53-dependent signal pathways. Cell 1997, 89:1175-1184

12. Lee CW, Arai M, Martinez-Yamout MA, Dyson HJ, Wright PE: Mapping the interactions of the p53 transactivation domain with the KIX domain of CBP. Biochemistry 2009, 48:2115-2124.

13. Sartorelli V, Huang J, Hamamori Y, Kedes L: Molecular mechanisms of myogenic coactivation by $\mathrm{p} 300$ : direct interaction with the activation domain of MyoD and with the MADS box of MEF2C. Mol Cell Biol 1997 17:1010-1026.

14. Kung AL, Wang S, KIco JM, Kaelin WG, Livingston DM: Suppression of tumor growth through disruption of hypoxia-inducible transcription. Nat Med 2000, 6:1335-1340.

15. Pao GM, Janknecht $R$, Ruffner $H$, Hunter $T$, Verma IM: CBP/p300 interact with and function as transcriptional coactivators of BRCA1. Proc Natl Acad Sci U S A 2000, 97:1020-1025.

16. Yang C, Shapiro LH, Rivera M, Kumar A, Brindle PK: A role for CREB binding protein and p300 transcriptional coactivators in Ets-1 transactivation functions. Mol Cell Biol 1998, 18:2218-2229.

17. Abraham SE, Lobo S, Yaciuk P, Wang HG, Moran E: p300, and p300-associated proteins, are components of TATA-binding protein (TBP) complexes. Oncogene 1993, 8:1639-1647.

18. Garbati MR, Thompson RC, Haery L, Gilmore TD: A rearranged EP300 gene in the human B-cell lymphoma cell line RC-K8 encodes a disabled transcriptional co-activator that contributes to cell growth and oncogenicity. Cancer Lett 2011, 302:76-83.

19. Gayther SA, Batley SJ, Linger L, Bannister A, Thorpe K, Chin SF, Daigo Y, Russell P, Wilson A, Sowter HM, Delhanty JD, Ponder BA, Kouzarides T, Caldas C: Mutations truncating the EP300 acetylase in human cancers. Nat Genet 2000, 24:300-303.

20. Ionov $Y$, Matsui S, Cowell JK: A role for p300/CREB binding protein genes in promoting cancer progression in colon cancer cell lines with microsatellite instability. Proc Natl Acad Sci U S A 2004, 101:1273-1278.

21. Kimbrel EA, Lemieux ME, Xia X, Davis TN, Rebel VI, Kung AL: Systematic in vivo structure-function analysis of p300 in hematopoiesis. Blood 2009, 114:4804-4812.
22. Eckner R, Yao TP, Oldread E, Livingston DM: Interaction and functional collaboration of $\mathrm{p300/CBP}$ and bHLH proteins in muscle and B-cell differentiation. Genes Dev 1996, 10:2478-2490.

23. Li M, Damania B, Alvarez X, Ogryzko V, Ozato K, Jung JU: Inhibition of p300 histone acetyltransferase by viral interferon regulatory factor. Mol Cell Biol 2000, 20:8254-8263.

24. Wang L, Grossman SR, Kieff E: Epstein-Barr virus nuclear protein 2 interacts with p300, CBP, and PCAF histone acetyltransferases in activation of the LMP1 promoter. Proc Natl Acad Sci U S A 2000, 97:430-435.

25. Cotter MA 2nd, Robertson ES: Modulation of histone acetyltransferase activity through interaction of Epstein-Barr nuclear antigen $3 \mathrm{C}$ with prothymosin alpha. Mol Cell Biol 2000, 20:5722-5735.

26. Sankar N, Baluchamy S, Kadeppagari RK, Singhal G, Weitzman S, Thimmapaya B: p300 provides a corepressor function by cooperating with YY1 and HDAC3 to repress c-Myc. Oncogene 2008, 27:5717-5728.

27. Kalaitzidis D, Davis RE, Rosenwald A, Staudt LM, Gilmore TD: The human B-cell lymphoma cell line RC-K8 has multiple genetic alterations that dysregulate the Rel/NF-KB signal transduction pathway. Oncogene 2002, 21:8759-8768

28. Compagno M, Lim WK, Grunn A, Nandula SV, Brahmachary M, Shen Q, Bertoni F, Ponzoni M, Scandurra M, Califano A, Bhagat G, Chadburn A, Dalla-Favera R, Pasqualucci L: Mutations of multiple genes cause deregulation of NF-KB in diffuse large B-cell lymphoma. Nature 2009, 459:717-721

29. von Mikecz A, Zhang S, Montminy M, Tan EM, Hemmerich P: CREB-binding protein (CBP)/p300 and RNA polymerase II colocalize in transcriptionally active domains in the nucleus. $J$ Cell Biol 2000, 150:265-273.

30. Puri PL, Sartorelli V, Yang XJ, Hamamori Y, Ogryzko W, Howard BH, Kedes L, Wang JY, Graessmann A, Nakatani Y, Levrero M: Differential roles of p300 and PCAF acetyltransferases in muscle differentiation. Mol Cell 1997, 1:35-45

31. Wertz IE, O'Rourke KM, Zhou H, Eby M, Aravind L, Seshagiri S, Wu P, Wiesmann C, Baker R, Boone DL, Ma A, Koonin EV, Dixit VM: De-ubiquitination and ubiquitin ligase domains of A20 downregulate NF-KB signalling Nature 2004, 430:694-699.

32. Krikos A, Laherty CD, Dixit VM: Transcriptional activation of the tumor necrosis factor a-inducible zinc finger protein, $A 20$, is mediated by $\mathrm{kB}$ elements. J Biol Chem 1992, 267:17971-17976.

33. Lim KH, Yang Y, Staudt LM: Pathogenetic importance and therapeutic implications of NF-KB in lymphoid malignancies. Immunol Rev 2012, 246:359-378.

34. Gilmore TD: Multiple mutations contribute to the oncogenicity of the retroviral oncoprotein v-Rel. Oncogene 1999, 18:6925-6937.

35. Luebben WR, Sharma N, Nyborg JK: Nucleosome eviction and activated transcription require p300 acetylation of histone $\mathrm{H} 3$ lysine 14. Proc Natl Acad Sci U S A 2010, 107:19254-19259.

36. Horwitz GA, Zhang K, McBrian MA, Grunstein M, Kurdistani SK, Berk AJ: Adenovirus small e1a alters global patterns of histone modification. Science 2008, 321:1084-1085.

37. Ferrari R, Pellegrini M, Horwitz GA, Xie W, Berk AJ, Kurdistani SK: Epigenetic reprogramming by adenovirus e1a. Science 2008, 321:1086-1088.

38. Seligson DB, Horvath S, Shi T, Yu H, Tze S, Grunstein M, Kurdistani SK: Global histone modification patterns predict risk of prostate cancer recurrence. Nature 2005, 435:1262-1266.

39. Kueh AJ, Dixon MP, Voss AK, Thomas T: HBO1 is required for H3K14 acetylation and normal transcriptional activity during embryonic development. Mol Cell Biol 2011, 31:845-860.

40. Love IM, Sekaric P, Shi D, Grossman SR, Androphy EJ: The histone acetyltransferase PCAF regulates p21 transcription through stress-induced acetylation of histone H3. Cell Cycle 2012, 11:2458-2466.

41. Thompson RC, Vardinogiannis I, Gilmore TD: The sensitivity of diffuse large B-cell lymphoma cell lines to histone deacetylase inhibitor-induced apoptosis is modulated by BCL-2 family protein activity. PLoS One 2013, 8:e62822.

42. Sambrook J, Fritsch EF, Maniatis T: Molecular Cloning: A Laboratory Manual. 2nd edition. Cold Spring Harbor, NY: Cold Spring Harbor Laboratory Press; 1989

43. Starczynowski DT, Reynolds JG, Gilmore TD: Mutations of tumor necrosis factor a-responsive serine residues within the C-terminal transactivation domain of human transcription factor REL enhance its in vitro transforming ability. Oncogene 2005, 24:7355-7368. 
44. Sun CC, Thorley-Lawson DA: Plasma cell-specific transcription factor XBP-1 s binds to and transactivates the Epstein-Barr virus BZLF1 promoter. J Virol 2007, 81:13566-13577.

45. Longe HO, Romesser PB, Rankin AM, Faller DV, Eller MS, Gilchrest BA, Denis GV: Telomere homolog oligonucleotides induce apoptosis in malignant but not in normal lymphoid cells: mechanism and therapeutic potential. Int J Cancer 2009, 124:473-482.

46. Liang M-C, Bardhan S, Porco JA Jr, Gilmore TD: The synthetic epoxyquinoids jesterone dimer and epoxyquinone $A$ monomer induce apoptosis and inhibit REL (human c-Rel) DNA binding in an IkappaBalpha-deficient diffuse large B-cell lymphoma cell line. Cancer Lett 2006, 241:69-78.

47. ImageJ. [imagej.nih.gov/ij/]

48. Chin M, Herscovitch M, Zhang N, Waxman DJ, Gilmore TD: Overexpression of an activated REL mutant enhances the transformed state of the human B-lymphoma BJAB cell line and alters its gene expression profile. Oncogene 2009, 28:2100-2111.

49. Lee Tl, Johnstone SE, Young RA: Chromatin immunoprecipitation and microarray-based analysis of protein location. Nat Protoc 2006, 1:729-748.

50. Amir-Zilberstein L, Ainbinder E, Toube L, Yamaguchi Y, Handa H, Dikstein R: Differential regulation of NF-KB by elongation factors is determined by core promoter type. Mol Cell Biol 2007, 27:5246-5259.

51. Livak KJ, Schmittgen TD: Analysis of relative gene expression data using real-time quantitative PCR and the 2(-Delta Delta C (T)) Method. Methods 2001, 25:402-408

52. Garcia BA, Mollah S, Ueberheide BM, Busby SA, Muratore TL, Shabanowitz J, Hunt DF: Chemical derivatization of histones for facilitated analysis by mass spectrometry. Nat Protoc 2007, 2:933-938.

53. Kuo YM, Andrews AJ: Quantitating the specificity and selectivity of Gcn5-mediated acetylation of histone H3. PLoS One 2013, 8:e54896.

doi:10.1186/1476-4598-13-29

Cite this article as: Haery et al: Histone acetyltransferase-deficient p300 mutants in diffuse large B cell lymphoma have altered transcriptional regulatory activities and are required for optimal cell growth. Molecular Cancer 2014 13:29.

\section{Submit your next manuscript to BioMed Central and take full advantage of:}

- Convenient online submission

- Thorough peer review

- No space constraints or color figure charges

- Immediate publication on acceptance

- Inclusion in PubMed, CAS, Scopus and Google Scholar

- Research which is freely available for redistribution 